\title{
Proximate Determinants of Women Empowerment: A Review
}

\author{
Neha and Mohammad Aslam Ansari* \\ Department of Agricultural Communication, College of Agriculture, \\ GBPUA\&T, Pantnagar, India \\ *Corresponding author
}

\section{A B S T R A C T}

\begin{tabular}{l} 
K e y w o r d s \\
Women \\
empowerment, \\
Gender equality, \\
Determinants of \\
women \\
empowerment, \\
Factors affecting \\
women \\
empowerment, \\
Status of women \\
\hline $\begin{array}{l}\text { Article Info } \\
\text { Accepted: } \\
\text { 26 September } 2020 \\
\text { Available Online: } \\
10 \text { October } 2020\end{array}$ \\
\hline
\end{tabular}

The quality of life and the status of women in a society are perceived to be reflective of the development status of a country. Women's status in the society, access to resources (material as well non-material) and freedom accorded in decision making is indicative of women empowerment. Although women's empowerment and the movement towards gender equality is not a recent phenomenon, it continues to evolve and engage the attention of everyone - politicians, researchers, administrators and policy makers- around the world. The process of empowering of the women is influenced by various independent factors called determinant and is a factor or cause that leads directly to decision making by women at various levels. Understanding the different dimensions of women empowerment is therefore important to develop relevant policies and programmes that may help to enhance the gender equality and triggers greater shifts in cultural norms to promote women's rights. This paper discusses various socio-cultural, economic, psychological, legal and political determinants of women empowerment.

\section{Introduction}

By looking at the condition and status of women in a society, you can tell the prevailing social matrix and the status of women. Empowerment in real sense doesn't necessarily mean high standards of living or longer lifespan or independence. In real sense, a women living in high society can still suffer if she is exposed to domestic violence or lack of freedom in decision making or denied equal property rights. One myth that we needs to address and discard at the very outset is the assumption that empowerment of women is necessary in rural areas only. The urban women, it may seem, could be better off in comparison, but they may still not fit the yardstick of women empowerment in real sense. Rana and Ansari (2019) stated that women empowerment is one of the critical issues in the development research and policy making in developing countries. It is a multidimensional concept and multifaceted process involving facilitation of women for 
action and involvement in social, economic and political spheres of life. Mandal (2020) conceptualized women empowerment in five separate categories - social, political, economic, psychological and educational; and reiterated that each of these categories is critical in facilitating access and control over resources, rights and freedom in decision making in key areas of her life.

Over the last three decades, gender equality and women empowerment are being focused around the world. Women are undoubtedly the backbone of a society without considering the women in policies and programs their conditions in the society will have negative effect on the development. Women are very important and integral part of a society without their participation in decision making we can't imagine the growth of the country. India is a democratic country where patriarchal values embedded in the culture and traditions which predetermine the social value of gender. In a traditional society, where all the decisions related to outside of the house are taken by the men or home is defined as a woman's legitimate ideological and physical space, they confined only in the four walls of the house. Over the years of the independence of our country still women facing the problem of sex discrimination and are deprived of their basic rights, education, health care, control over resources, nutritional deprivation, etc. India is a male dominated society where women are considered inferior relative to men even in the $21^{\text {st }}$ century. Therefore, in a patriarchal society gender equality is very difficult to achieve where societies and communities are governed by such type of strict restriction of social and cultural norms. As the present scenario is changing therefore, empowering women is the need of the hours and can be viewed as the crucial aspect in the economic and sustainable development of the country.
In the International Conference on Population and Development (ICDP) in Cairo, Egypt organized by United Nation in 1994 emphasized the need to address "Gender Equality, Gender Equity and Women Empowerment. They defined women empowerment in terms of elimination of sex discrimination, eliminating violence, involvement in political and public life sphere, equality between women and men, involvement in decision-making, economic self-reliance, and access to education.

Fourth World Conference on Women in Beijing in 1995 marked a significant turning point for the global agenda for gender equality. It sets objectives and actions for the advancement and development of women empowerment and the achievement of gender equality in 12 critical areas these are; The persistent and increasing burden of poverty on women; Unequal and inadequate access to education and training; Unequal and inadequate access to health care, nutritional care, etc.; Violence against women;

The effects of armed or other kinds of conflict on women; Inequality in economic structures and policies, in all forms of productive activities and access to resources; Inequality between men and women in the sharing of power and participation in the decisionmaking at all levels; Insufficient mechanisms at all levels which affect the advancement or empowerment of women; Lack of respect and inadequate promotion and lack of protection of the human rights of women; Stereotyping of women and inequality in women's access to and participation in all communication systems, especially in the media; Gender inequalities in the management of natural resources and in the safeguarding of the environment; and persistent discrimination against and violation of the rights of the girl child. At the conference, governments from across the world agreed on this 
comprehensive plan to achieve global legal gender equality and women empowerment, known as the Beijing Platform for Action.

The importance of empowering women found in the Millennium Development Goals (MDGs), 2000 which has developed "eight goals" in which the goal three is focused on "to promote gender equality and women empowerment" in order to achieve sustainable development and economic growth, although, women constituted about 50 percent of the total world's population so, need to transform this larger women's population force as an effective human resource and this is possible only through the empowering women.

Empowerment of women will have a powerful positive impact on the wellbeing as well as on the family, society and economic development. As women have always been neglected in the development process and deprived of their basic needs, health, education, and information, access to power and authority, and decision-making.

Therefore, it is required that women must come forward to take the challenges and to overcome the deeply rooted existing disparities in the societal structure to improve their conditions of lives and the lives of their families and wider communities. Hence, the relevance of empowering of women become essential to cope up with their poor status and help them to gain self-confidence, knowledge, gain experience, economic support to family and bring up their children in a more effective manner and contribute to the family's and other decisions. It will also create awareness and exposure among women to enhance their ability to get equal opportunities and an equal position at the managerial level, contributing to the organization and to build strong foundations for inclusive growth of the nation.

\section{Concept of empowerment}

Empowerment is a dynamic process which takes place at multiple levels. The important word in empowerment is power which means the ability to make choices. "Power is the capability to do anything" and in the social context power can be considered "as the authority, right to command, right to govern or rule, capability to influence others, etc. Kabeer (1998) defined power as the ability to make choices that means those who are disempowered either they denied or have limited in their choices. Thus, empowerment is a process to give power those who are the disempowered and can enhance their ability to make strategic choices. World Bank defined empowerment as an individual's or group's capacity to make choices and transform these choices into actions. The outcomes of empowerment are just the expansion of freedom of choices and actions. Bennett (2002) defined empowerment as the enhancement of assets and capabilities of individuals or group to engage influence and ensure accountability of the institutions which affect them. Sen (1999) defined empowerment as altering relations of power, which affect women's options or autonomy and adversely affects well being. Mason (1986) refers to empowerment as ability as making effective choices.

Basically, Empowerment has three elements:

Access to assets such as land, credit and various technologies,

Access to basic needs such as education, health services, water, shelter etc.

Equal participation in decision making, etc.

Empowerment is a platform for creating a social environment in which one can make decisions and their choices either individually 
or collectively for social transformation. It enhances the natural ability of acquiring knowledge, power and experience of an individual (Hashemi, Schuler, and Riley, 1996). Empowerment is the process of enabling or authorizing individual to think, take action and control work in an autonomous way. It is the process by which the powerless becomes able to gain power and they have greater control over one's destiny and the circumstances of one's lives.

Empowerment includes both control over resources (Physical, human, intellectual and financial) and over ideology (beliefs, values and attitudes), (Batliwala, 1994). Empowerment means to have greater selfconfidence, and an inner transformation of one's consciousness that enables one to overcome external barriers to accessing resources or changing traditional ideology (Sen and Batliwala, 2000). Empowerment is not merely a feel of greater extrinsic control, but also grows intrinsic capacity, self confidence and an internal transformation of one's consciousness that enables one to overcome external barriers to accessing resources or changing traditional ideology (Pinto, 2001).

Rawland (1997) defined the process of empowerment and how power can take many different forms.

Power over: Such type of power emphasized only on the ability to influence, force, coerce, domination and control over others. This is mainly focused to create fear over others and the belief of power over is that power has finite resources but such resources only held by an individual.

Power to: Power to refer to productive or generative power. Power to mainly focus to organize and change existing hierarchies which means to create new possibilities and actions without any domination of either one side. Such type of power emphasis to make a difference among various choices and to achieve goals by creating something new.

Power with: Power with is the consequences of collective actions, collaboration and relationships among peoples. This belief on respect, mutual support, collaborative decision-making which provides a platform for social power and enhance the ability of individual to act together effectively.

Power from within: It means to increase consciousness of an individual. The basis of the power is individual's strength, self respect, uniqueness, and self acceptance that lead to respect and acceptance of others as equals.

Kabeer (1998) has emphasized that the ability of an individual to make strategic life choices is based on three interrelated elements and these are Resources, Agency and Achievement;

Resources: Resources are defined as the conditions or options of choices, or meaning that one's perceives or ability to choose available alternatives. This can also be understood as the material, human and social expectations and allocations of available resources. Kabeer (1998) defined resources as the pre- conditions. Resources are the medium through which agency are exercised and further leads to achievements which is the outcomes of agency. Resources are distributed through institutions and relationships in a society (such as family, market, community, etc.) which serve to enhance the ability of an individual to exercise on these available choices. Access to resources is facilitated by the established rules and norms which are governed by these institutions and societal relationships; they have certain actors in a position in order to 
determine the principles of distribution and exchange of resources in different institutions and societies. Such as head of households, managers of organizations and elites within a community they all have decisions making authority in particular institutions by virtue of their position. Thus, the way in which resources is to be distributed depend only the ability to define their priorities and enforce claims. If these institutions and societal relationships promote male authority and endorse gender inequality consequently, access to resources and women capacity to make strategic choices is likely to be limited.

Agency: Agency can be defined as the process through which choices are made or the power of ability or sense of power within or defines one's goals, and act upon these goals and one has ability to make decisions on their strategic life choices. Agency defines that how one sees themselves (i.e. sense of self-worth) which is the foundation of empowerment's process. Agency can be operationalized as decision making ability, like bargaining and negotiation, deception and manipulation, subversion and resistance as well as more intangible, cognitive process of reflection and analysis is the form of agency. Agency is exercised by individuals as well as by collective activities.

Agency has both positive and negative connotations in relation to power.

In the positive sense of the 'power to' - refers to people's capacity or ability to make their own strategic choices and act upon it, to pursue their own goals, even in the face of opposition from others and even unfavorable situations for them.

In the negative sense - the 'power over' refers to the capacity of some actors to override the agency of others through the exercise of authority or the use of violence, threats and other forms of coercion. When both resources and agency constituted together called capabilities and these capabilities enable help peoples to act effectively and achieve their goals and the outcomes of these acts would be the achievements.

Achievement: When resources and agency constituted together called people's capabilities that are the potentials for living the lives they want. Then, the term achievement can be understood as outcomes or consequences of the choices made by individual. This can also be referred to the extent to which the potential one's capabilities (i.e. resources and agency) for living their lives as they want are realized or fail to be realized and the outcomes of people's efforts. In relation to empowerment, achievement can be considered in both terms either as the agency exercised or its consequences.

\section{Concept of women empowerment}

Women Empowerment as a concept introduced at the International Women Conference in 1985 at Nairobi, which defined it as redistribution of social power and control over resources in favor of women relative to men. The United Nations claimed the year 2001 as the 'International Year for Women's Empowerment' after declaring the 'Women's Decade' in 1975. In the year 2001 India also declared as the 'Women's Empowerment Year'. Rana, Ansari and Gangwar (2018) observed that Women's empowerment refers to the process by which women acquire due recognition on par with men, to participate in the development process of the society through the political institutions as a partner with human dignity. Further, Empowerment provides a greater access to knowledge and resources, more autonomy in decision making, greater ability to plan lives, more control over the circumstances which influence lives, and freedom from customs, belief and practices (Rana and Ansari, 2018) 
As the empowerment means acquiring the power to think and act freely, make a choice and take a decision in an autonomous way. Women empowerment means making women self-dependent by giving them freedom of access to education and economic opportunities etc. Women empowerment is a process of encouraging women to participate equally in developmental activities, giving them freedom of mobility, power of speech and having access to resources so on. Women empowerment is a process of improving their position in power structure of the society (Awan and Iqbal, 2015).

According to UNDP, 2014 women empowerment is a process of change in which women can rebuilt or acquire the capability of taking decisions and support themselves and their family members through financially and morally. Bali (2006) defined women empowerment as a practice of providing suitable environment to women against prevailing norms, culture and traditions and to enhance their well-being. Kabeer (1998) explained women empowerment as the process to acquire the ability to make the strategic life choices that restricted through poverty particularly and societal or religious norms generally in a society. Women can make a contribution in household decisionmaking and process and family income through empowerment (Hossain and Jaim, 2011 and Yusuf, 2010). Dreze and Sen (1995) defined women empowerment as ability to define self-interest and choice, and consider woman as not only able but also entitled to make choices.

The level of women's empowerment can improve by reducing gender biasness, mortality rate, access to education and professional training, in employment, the ownership of property and household work and decision making.
Empowering women is a process through which women would be able to transform their self-perceptions equivalent to enchantment of transforming gender roles. Although, empowerment and development are closely related thus empowerment helps to achieve sustainable development and this is prerequisite to gender equality and development.

According to UNFPA report," the state of World Population 1992, said that we can't image sustainable development of any country, because it is only women who contribute for most the development, for their children and family health. Thus, the process of women empowerment should start from their own home and women's positions in the household determines their autonomy in the family. It is worth to examine the extent to which they can take any decisions about household like buying household assets, access to money, and freedom of mobility to go their relative's house etc.

Although, women empowerment is the crucial part of development policies of any developing countries, yet they are facing many problems. Though women can make a great contribution in the development process, but still they have low status as compared to men (Khan, 2010). There are some problems or barriers of women empowerment;

Gender Discrimination.

Lack of proper educational programs.

Child or early marriage and dowry system.

Financial constraints and economically dependent on men.

Patriarchal or patrilineal order and the subordinate status of women.

Lack of health care and safety.

Professional inequality, particularly workplace harassment.

Inequality in sharing the burden of household work. 
According to United Nations Women Policy Division (2013), women empowerment needs to be focused and all the developmental programs and policies should be focused on gender sensitization. In developing countries, due to early marriages, there are high rates of women unemployment being faced along with limited investment.

In the modern age, women have shown their potential and excellence in all fields. They have proved it they are equal to men. But societal set-up and sex-based discrimination have been continued to dominate in the society by depriving women all sort of facilities. Empowering women is the need of the hours as it is the major cause of hurdle in the progress and development of the country.

Thus, women's power has to be understood and channelized in the progress. Not only women but also men also need to understand and realize their responsibilities and share them in the development because both are equally important.

Women also need to change their mindset and raise their voice issues and need to identify their potential and no need to think themselves as weak but become psychological, mentally and physically strong. Women empowerment has the potential to change the face of country.

\section{Levels of women empowerment (Longwe, 1995)}

The Longwe Framework focused on the concept of "five levels of equality", and indicates the extent to which women are equal to men, and they have achieved empowerment. The levels of equality can be used to measure the likelihood of particular development interventions those promoting equality and women empowerment.
Welfare: Welfare is the degree in which basic material needs of women are satisfied such as food, income, and medical care etc. At this level women considered only as a passive recipient.

Access: This level defined as the women's equal access to resources with men such as education, labor, credits, market facilities, public services, etc. Reforms of law and governmental policies are required for such equal access to resources.

Conscientization: This level focused on raising awareness level of women. Make aware women about the differences between gender roles and help them to understand that gender roles are only culturally defined thus it can be changed. At this level structural and institutional discrimination is addressed and can be challenged. Women believe that gender role can be changed thereby, possible to achieve gender equality. Pertains that gender relations and gender divisions of labor should be fair and agreeable to both sides and it is not based on the domination of one over the other.

Participation: It is a degree of selfmobilization of women. Women ensure their equal participation in decision-making process, policy making, and planning and administration levels. Equal participation means involving women in the decisions making by which their community will be affected, and their participation match with the proportion of wider community.

Control: It is a degree where women can make decision which is fully recognized and this denotes as the control over the decision making process through conscientization and mobilization by having balance control over production and distribution of benefits without dominance or subordination of one side. 
What researchers say about women empowerment: A Review of reviews

Malhotra and Mather (1997) in a study on "Do schooling and work empower women in developing countries? Gender and domestic decisions in Sri-Lanka" they considered two dimensions of empowerments; financial matters decision-making and decision making in social and organizational matters. They found that education and employment of women were highly associated with their control over financial matters, and women's family structure was more associated with their control over social and organizational matters. Jejeebhoy (2000) in a study on "Women's autonomy in rural India: Its dimensions, determinants, and the influence of Context" they compared the women and household characteristics on women's autonomy between the two regional and culturally different states Tamil Nadu and Uttar Pradesh. She measured women's autonomy and included four dimensions that were role in decision-making, mobility, incidence of domestic violence, and access to economic resources and control over economic resources. She found that traditional characteristics; the number of sons, dowry size and nuclear family type were directly related with the autonomy indicators in respective culture of Uttar Pradesh relative to Tamil Nadu state. In Uttar Pradesh state found that women employment and women education had positive and negative impact on their autonomy respectively. Whereas in Tamil Nadu state women employment and women education both had positive impact on their autonomy respectively.

Haque et al., (2011) in a study on "Women Empowerment or Autonomy: A comparative view in Bangladesh" measured women empowerment and autonomy and distinguished each other by constructing three specific dimensions in Bangladesh namely;
Economic decision making, Household decision making, and Physical movement. They found that the level of women autonomy decreased with the low level of education whereas education increased the level of women empowerment. Whereas, women's current age, place of residence, education, religion, and media exposure were the important factors that affecting women empowerment and their autonomy.

Islam et al., (2012) in a study on "Determinants of Empowerment of Rural Women in Bangladesh" those who were engaged in poultry rearing practices. They found that husband's behavior, independence in spending money, independent decision making authority, involvement in family affairs, control over poultry rearing practices, position in the family of women were the determinants of women empowerment. They found that poultry rearing programs improved women's empowerment status by their economic condition and enhanced their ability to contribute more to their family financially.

Bushra et al., (2014) in a study on "Assessing the Socio-Economic Determinants of Women Empowerment in Pakistan" the result showed that the content of education, economic participation of women, poverty and economic opportunity available for women increased their empowerment. While those women having a bank account were showed an extreme significant positive impact on women empowerment. This was supported only by the economic opportunities available to them that increased their power. Finally, it was concluded that these significant factors had influence on women empowerment, therefore, one could focus on these determinants to increase and enhance women's role in our society.

Awan and Zertashia (2015) in a study on "Determinants of Women Empowerment: A 
case study of District D.G. Khan in Pakistan" found that access to media, having a bank account, and doing any paid job had positive impact on women empowerment. While women having a joint family system and facing fear of violence from father/husband had significant negative impact on women empowerment.

Abshoko et al., (2016) in a study on "Determinants of Socio-Economic Empowerment of married Women: Evidence from Ethiopia" revealed that women's level of education, employment status, earning compared to husbands, exposure to media, place of residence, age at first marriage, family size and attitude towards wife beating were found major determinants of empowerment and negatively affected women's participation regarding social and economic matters in a household.

Sharma et al., (2016) in a study on "Determinants and Indicators of Women Empowerment: A walk through psychological patterns and behavioral implications in Delhi". The study framed three determinants these were psychological patterns of society, family and women and they found that these three determinants had influenced on six indicators these were education, educational freedom, economic contribution, economic freedom, household management and decision making, perceived status within the household and health and had direct influenced on the status of women empowerment. The study suggested that women need to take actions for their rights and strongly raise their voices about gender equality in order to separate themselves from the traditional paradox those considered woman as a commodity and need to be kept at home.

Soharwardi, Khan and Khalid (2014) in a study on "Socio-Economic Determinants of Women Empowerment in Pakistan". The determinants were Economical (decision of earning, decision of spending money), Education (decision of children education), Health (Decision of Family planning and baby delivery) and Political (Decision of voting). They found that related to earning and children's education decisions were taken only by husband. Decisions about baby delivery were taken by both husband and women. Further, decisions about spending money and voting decisions were taken by only husband.

Khan et al., (2016) in a study on "Determinants of Women's Empowerment and Poverty reduction: A case study of rural Faisalabad, Punjab" the most important finding of the study was that the households where women had higher decision making authority were better-off and in other words women empowerment was likely to alleviate poverty and increased household wellbeing.

The results also revealed significant positive relationships between women age, education, decision making authority and paid work involvement with empowerment and poverty reduction. It was also found that education is the most important factor in empowerment of women but still majority of respondents $(64.5 \%)$ had only up to 5 standard level of education, most of the women had very limited decision making authority and control over economic resources. Mostly all important decisions and resources were controlled by the male of the households. Similarly, 65 percent of the respondents said that decisions regarding family size were taken by both husband and wife. Freedom of mobility is one of the pillar of empowerment and it helps to alleviate poverty but the results of the study showed that very small percentage of respondents had full freedom of mobility to go outside the house and their relative's house and 80 percent of the respondents needed permission from their family to go to the local market. 


\section{Conceptual framework}

World Bank (2011), defined women empowerment as the expansion of the freedom of choices and actions, and helps to increase women's authority and control over resources and decisions making regarding with their life. World Bank identified women empowerment as the successful key to alleviate poverty, enhance growth and encourage better governance. The process of women's empowerment should start from their own home and the position of women in the household determines women's autonomy in the family. Women's empowerment can be determined through the role of women buying household assets and jewelleries, access to money, mobility to go their relative's house and access to health care facilities, etc. According to UNFPA, empowerment of women refers to giving legitimate or decision making power to women in social, economic and political sphere of life to perform tasks.

In 1994, ICPD-POA (International Conference on Population \& Development Program of Action), Cairo, said that the empowerment of women and the improvement of their political, social, and economic and health status are highly important to any country for the achievement of sustainable development and economic growth.

The equal participation and partnership of both women and men are required in productive and reproductive lives for the care and nurturing of children and maintenance of the household as well as. But across the world, still women facing threats to their lives, health and well- being as a result of being overburdened with work and of their lack of power and influence. In developing countries women are less in formal education than men, and at the same time, women's knowledge, abilities and coping mechanisms often unrecognized.

Empowerment of women from grass root level is a need of modern era to fight against poverty, sustainable economic growth and food insecurity. Changes should require in policies and programs actions that will help to improve women's access to secure their livelihoods and economic resources, alleviate their extreme responsibilities with regard to housework, and remove legal impediments to their equal participation in public and personal life. Need to raise social awareness through effective programs of education and mass communication. Improvement in the status of women also enhances their decisionmaking capacity at all levels and in all spheres of their life.

Keeping in view there is a dire need of women empowerment and to investigate determinants of women empowerment. Based on previous researches there can be four categories of determinants of women empowerment these are socio-cultural, economic, legal and political, and psychological determinants of women empowerment.

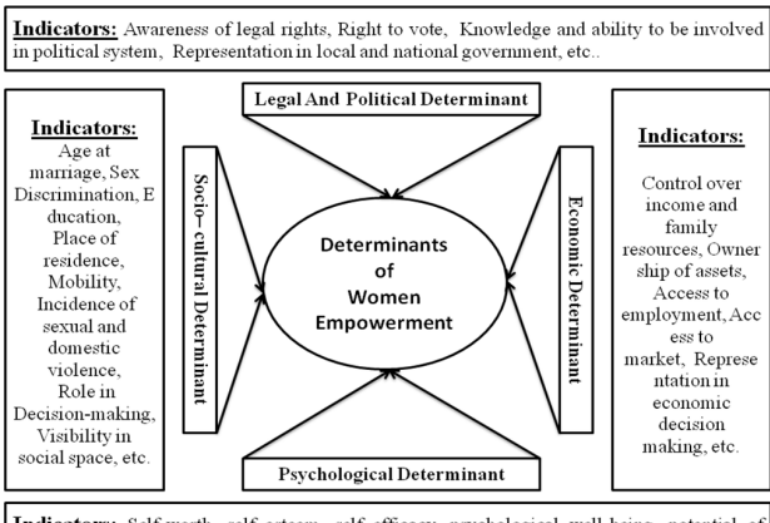

Indicators: Self-worth, self esteem, self efficacy, psychological well-being, potential of mobilization, Risk taking ability, etc

\section{Socio-cultural determinants}

Socio-cultural factors are deeply rooted in our society and men or women are conceptually divided into two separate worlds, home is 
defined for woman, while the world outside the home is defined for man. Due to cultural practices gender roles have been constructed for men or women and these gender composition is the main cause of gender inequalities, from a very young age girls are expected to learn domestic skills such as cooking, sewing, washing, cleaning, and child caring etc. In rural areas, it is belief that a son should be educated because he will need to support his aged parents whereas a daughter who after her marriage will serve another family, with such beliefs, most families prepare their girls for marriage. Girls are taught to be obedient and quiet, must follow the leading roles played by males. Women are expected to take on the responsibility for bearing and rearing children, and thereby, this responsibility not only precludes them in attending school but also prevents them from external jobs. Women are considered as the non-permanent member of the family while sons are considered as the asset of the family and women disadvantage due to our societal composition. These entrenched socio-cultural beliefs are the major factor of women empowerment. These old traditions and practices have fixed in the mindset of Indian society. Thus, here is a need to strengthen and improvement of their social position in society which is predominantly patriarchal and it may have strong influence on individual's personality, attitudes, and lifestyle of women. There are some indicators of socio-cultural determinants that may have influence on women empowerment include age at marriage, sex discrimination, having access to family planning services, caste, place of residence like urban and rural, freedom of mobility, caste, marital status, incidence of sexual and domestic violence, equal participation in decision-making, visibility in social space, and education, availability of health care, life expectancy rates and fertility rates, etc.

\section{Economic determinants}

Women empowerment and economic development is closely related and is a powerful tool to fight against poverty. Women's economic participation is the key to strengthen women's rights and make them enable to have control over their lives through which they can establish a place for themselves in society. The Women's conference in Beijing platform (1995) suggested that there is a need of women's economic independence and is essential to realize women's rights to achieve sustainable economic development, and poverty alleviation. Economic empowerment of women is not only helpful for women but more our society. Economically empowered women contribute to more their family, their children, and their societies, consequently, national economies lead to sustainable development. SEWA (Self Employed Women's Association) has emphasized on the economic empowerment of women and assessed that raising voice and visibility is not possible unless there is an access "to the ownership of economic resources by the poor women. There are some indicators of economic determinants of women empowerment may include control over income and family resources, ownership of assets, access to employment, access to market, and representation in economic decision making roles etc.

\section{Legal and political determinants}

Refers to voluntary activities as members of a society, in the selection of rulers and formation of public policy and programs. Gender equality and women's empowerment both are human rights necessary for achieving comprehensive, unbiased, and sustainable development. Therefore, women should involve actively in government and politics in order to maintain democracy. Global statistics 
showed that women are under-represented as leaders, elected officials, and voters due to deeply rooted cultural and social norms in a society; thereby, their participation in the political process is limited. Women political empowerment is a major measure of women empowerment and thus, the participation of women in political sphere becomes essential through which they can achieve gender equality in society that will help to speed up the process of nation development. Legal empowerment provides the framework for legislation that expands knowledge and awareness of legal rights. It also provides the opportunity to mobilize the women's right laws and utilization of the judicial system. Established rule and law in a society help to prevent the exploitation of an individual by another, and protect their rights and also bring awareness especially in women towards their rights. There are some indicators of political determinants of women empowerment include the right to vote, knowledge and ability to be involved in political system, representation in local and national government.

\section{Psychological determinants}

Psychological empowerment has been defined as an individual's cognitive state and the development of feeling to act upon for the improvement of their conditions and formation of the belief that they can succeed in change efforts". Oladipo (2009) considered psychological empowerment as a multifaceted construct which reflects the different dimensions of being psychologically enabled, and can be conceived as a positive integrate of perceptions of individual's personal control, a proactive approach to life, and is a critical understanding of the socio-political environment, which is rooted firmly in a society framework that includes community change, capacity building, and collectivity. An understanding of the psychological patterns of the women themselves is very critical in identifying the women empowerment dynamics. It is important to check if the will to liberate (from psychological conditionings) and thereby to empower does exist among the women.

There are some Psychological determinants may affect the empowerment of women include self awareness, high self esteem, self confidence and courage, understanding about own rights, privileges, roles \& responsibilities, power of self determination, positive attitude, risk taking ability, the power to face challenges of daily life, gaining knowledge and new ideas and skills, great relief from mental stress and anxiety, leading a happy and satisfied life and so on.

In conclusion the women are the key constituents of society and can play a catalyzing role in the process of development, and help in enhancement of economic, political and socio-cultural matrix for development. They have been faced with many challenges due to limited access to credit, health, education, decision making, etc. Empowering women is essential not only for their own well being as well as for the upliftment of families and communities. Therefore, there is an urgent need to raise the social, economic, health and psychological status of women. There is a need for appropriate policies and actions at grassroots level to ensure equal access to education, fair wages, safe working conditions, equal rights, credits, and access to assets, etc.

Societies and Polices must take initiatives to create a suitable climate for women so that there is no discrimination, and they have equal access to available resources and opportunities. This is not possible without women; they must come up with their new self-identity and self-worth in the male dominated society. 


\section{References}

Abshoko, A.D., Terye, N.D., and Shamenna, A.T. 2016. Determinants of socioeconomic empowerment of married women: Evidence from Ethiopia. Humanities and Social Sciences, 4(3): 66.

Arnoff, Elly. 2011. A literature review on the conceptualization of women's empowerment. Accessed online at https://doi.org/10.17615/dh5h-4p40

Awan, A.G. and Zertashia.2015. Determinants of women empowerment: A case study of district D.G. Khan. Journal of Developing country Studies, 5(14): 65-73.

Bali, S.R. 2006. Microfinance and women empowerment. SIDA, Stockholm, Baltimore: Published for resource the future, Johns Hopkins Press.

Bennett, L. 2002. Using empowerment and social inclusion for pro-poor growth: a theory of social change. Working Draft of Background Paper for the Social Development Strategy Paper. Washington, DC: World Bank.

Bushra, A., and Wajiha, N.2015. Assessing the socio-economic determinants of women empowerment in Pakistan. Procedia-Social and Behavioral Sciences, 177: 3-8.

Caren, G., Bahadur, C., Handbury, J., and Elson, D.2008. The financial requirements of achieving gender equality and women's empowerment. Mayra Buvinić et al., equality for women: where do we stand on Millennium Development Goal, 3.

Chaudhry, I. S., Nosheen, F., and Lodhi, M. I. 2012. Women empowerment in Pakistan with special reference to Islamic viewpoint: An empirical study. Pakistan Journal of Social Sciences, 32(1): 171183.

Dandona, A.2015. Empowerment of women:
A conceptual framework. The International Journal of Indian Psychology, 2(3): 35-45.

Desai, M.A.2010. Hope in hard times: Women's empowerment and human development. UNDP-HDRO Occasional Papers.

Francina, P.X., and Joseph, M.V.2013. Women empowerment: The psychological dimension. Rajagiri Journal of Social Development, 5(2): 61-74.

Haque, M., Islam, T.M., Tareque, M.,and Mostofa, M. 2011. Women empowerment or autonomy: A comparative view in Bangladesh context. Bangladesh e-Journal of Sociology, 8(2): 17-30.

Islam, N., Ahmed, E., Chew, J.,and Netto, B.D. 2012. Determinants of empowerment of rural women in Bangladesh. World Journal of Management, 4(2):36 - 56.

Jejeebhoy, S.J. 2000. Women's autonomy in rural India: Its dimensions, determinants, and the influence of Context. Population and Development Review, 27(4):687-712.

Kabeer, N.1999. Resources, Agency, and Achievements: Reflections on the measurement of women's empowerment. Development and Change, 30: 435-464.

Khan, I.A. Shahbaz, B., Naz, M, Umber,S. and Amir, R. M.2016. Determinants of women's empowerment and poverty education: A case study of rural Faisalabad, Punjab. Pakistan Journal of Agricultural Sciences, 53(4):217-225.

Khan, M., and Mazhar, S. 2017. Sociocultural impediments and women empowerment. International Journal for Innovative research in Multidisciplinary field, 3(7): 413-416.

Malhotra, A., and Mather, M. 1997. Do schooling and work empower women in 
developing countries? Gender and domestic decisions in Sri Lanka. Sociological forum, 12(4):599-630.

Mujahid, N., Ali, M., Noman, M., and Begum, A. 2015. Dimensions of women empowerment: A case study of Pakistan. Journal of Economics and Sustainable Development, 6(1):37-45.

Mamatha, B.S. 2018. Conceptual understanding of women empowerment in India. International Journal of Humanities and Social Science Research, 4(2): 90-94.

Mandal, K.C.2013. Concept and types of women empowerment. International Forum of Teaching and Studies, 9(2): 17-30.

Mandal, Keshab C. 2020. Five types of women empowerment. Available online at https://thriveglobal.com/stories/fivetypes-of-female-empowerment/

Mason, K.1986. The status of women: Conceptual and methodological issues in demographic studies. Sociological Forum, 1(2):284-300.

Oladipo, S. E. 2009. Psychological empowerment and development. Edo Journal of Counseling, 2(1): 118-126.

Presser, H., and Sen, G.2000. Women's empowerment and demographic processes: Moving beyond Cairo. Oxford University Press.

Rana, Kiran and Ansari, M. A. 2019. Women Empowerment through Self Help Groups: A Study in North Himalayan State of India. Journal of Community Mobilization and Sustainable Development, 14(3):389-396.
Rana, Kiran and Ansari, M. A. 2018. Self Help Group \& Woman Empowerment: A Study on Some Selected SHGs in Dehradun District. International Journal of Current Science and Technology, 6(2):546-550.

Rana, Kiran, Ansari, M. A. and Gangwar, R. R. 2018. Women's empowerment and SHGs: a case study from Uttarakhand. International Journal of Agriculture Science, 10(6):5447-5449.

Rathiranee, Y. 2013. Women empowerment through decision making. The International Journal of Economics and Business Management, 3(1).

Sahay, Sushma. 1998. Why empower women? In: Women and Empowerment: Approaches and Strategies. New Delhi: Discovery Publishing House.

Sen, A. 1999. Development as Freedom. Oxford: Oxford University Press.

Sharma,G.D. and Sanchita. 2017. Determinants and indicators of women empowerment: A walk through psychological patterns and behavioral implications. Research Journal Of Business Management, 11(1):15-27.

Soharwardi, M. A., Khan A.S., and Khalid, M. 2014.Socio-economic determinants of women empowerment: A case study of Cholistan Desert, Pakistan. International Journal of Scientific and Engineering Research, 5(11).

UNFPA. 1994. Women empowerment. Accessed online at https://www.unfpa.org/resources/issue7-women-empowerment

\section{How to cite this article:}

Neha and Mohammad Aslam Ansari. 2020. Proximate Determinants of Women Empowerment: A Review. Int.J.Curr.Microbiol.App.Sci. 9(10): 3271-3284. doi: https://doi.org/10.20546/ijcmas.2020.910.391 